\title{
SOULS IN EXILE AND LOST IDENTITIES IN HOTEL DU LAC ${ }^{1}$
}

\author{
Yrd. Doç. Dr. Şeyda İNCEOĞLU \\ Pamukkale Üniversitesi, Fen Edebiyat Fakültesi, \\ Batı Dilleri ve Edebiyatları Bölümü
}

\begin{abstract}
In every age, women are intruded on by patriarchal society which breaks into their lives and their bodies, and so commodifies them, to be used and abused by the patriarchs as tools of the ideological male point of view. In Hotel du Lac, the protagonist Edith Hope, writer of romantic fiction under the pseudonym Vanessa Wilde, is sent to Hotel du Lac for rehabilitation since she reacts against the voices of patriarchal ideology. This study, establishing a connection between the setting and the atmosphere of the novel with that of detective fiction, will analyse Edith's desire to be in control of her own life while ignoring patriarchal societal norms. The theory of the alienation of meaning in the detective story will be analysed in terms of the protagonist Edith Hope's alienation both from herself and her society in which she is seen as a threat, either as a detective or a victim, who is awakened to the restoration of disembodied signs in the setting of Hotel du Lac.
\end{abstract}

Keywords: Anita Brookner, flâneur, Hotel du Lac, gender, identity, alienation.

\section{HOTEL DU LAC'TAKİ SÜRGÜN RUHLAR VE KAYIP KİMLİKLER}

\section{ÖZ}

Her dönemde, kadınların yaşamları, erkek egemen toplumun hayatlarına müdahale etmeleri ile bölünmüş, ataerkil bakış açısılla toplum tarafindan kadın bedeni, kullanabilecekleri ve taciz edebilecekleri bir ürün haline dönüşürrülmüştür. Anita Brookner'ın, Hotel du Lac romanında, kullandı̆̆ romanların yazarı olan başkahraman Edith Hope, ataerkil toplumsal sisteme uymadiğ gerekçesi ile düzene uyumlu bir rehabilitasyonla kendine gelebilmesi için yine bu sistemin temsilcisi olan en yakın arkadaşı Penelope tarafindan Hotel du Lac'a gönderilir. Bu çalışmada, romanın geçtiği yer ve ortam ile detektif romanlarının kurgusu karşılaştırllarak Edith'in toplumsal düzeni göz ardı ederek kendi tanrılı̆̆ını ilan etmeye çalışması analiz edilecektir. Detektif hikâyelerindeki değerlere olan yabancılaşma, detektif ya da kurban olarak Edith Hope karakterinin kendine ve topluma yabancılaşması sonucu farkına vardı ğ parçalara ayrılmış işaretleri Hotel du Lac'ta yeniden oluşturması çerçevesinde incelenecektir.

${ }^{1}$ Makalenin geliş tarihi: 16.02.2015

Makalenin kabul tarihi: 05.03.2015 
Anahtar Kelimeler: Anita Brookner, flâneur, Hotel du Lac, kimlik, sosyal cinsiyet, yabancılaşma.

"Pour out your poison that it may refresh us! This fire burns our brains so fiercely, we wish to plunge To the abyss' depths, Heaven or Hell, does it matter? To the depths of the Unknown to find something new!'”

Charles Baudelaire, "Le Voyage"

\section{Introduction}

As Baudelaire says in his poem Le Voyage, one needs to travel to the depths of heaven or hell to reveal the unknown, the secrecies of the universe and to liberate the mind that is trapped by traditional discourses which religiously, culturally or politically alienate people from time and place they belong to. One's physical and spiritual state of attachment to time and place conception is usually the unconscious state of mind, in which one feels some kind of attachment for no reason. At a moment of crisis, when questioning starts in the mind, alienation from the meaning of self, society, and culture starts. In the postmodern sense, it is almost impossible to achieve the union of body and soul because human beings have become the authors of the destruction of humanity in the twentieth century. Post-war mentality leads to the feelings of alienation, freedom, despair and nothingness and urges human beings to fill this emptiness left by the wailings of despair of the sorrowful consequences of world wars in the twentieth century. However, the female suffered most from this emptiness and despair since she is trapped in the 'man-made world'. In this study, the hypocrisy within society which causes discontinuity, disruption, dislocation, and decentredness in individuals, is going to be analysed in Anita Brookner's Hotel du Lac which portrays the female protagonist Edith Hope in search of a social identity rather than a female identity. The perspective of gender and culture, and quest for a social identity which is destroyed and doomed to the loss is going to be linked to the ideology of detective fiction.

Hotel du Lac as a quest story of Edith Hope can be read like a detective story in which there are no physical deaths but lots of symbolic murders of females committed by their male-dominated society. In Hotel du Lac, to create hope for both herself and society Edith assumes the role of the detective in a metaphorical sense not only by revealing the secret identity of others but also of herself. Establishing a connection between the setting and the atmosphere of the novel with that of a detective fiction, female desire to be a god of her own life ignoring patriarchal societal norms is going to be scrutinized in this paper. 


\section{Disembodied Signs in Exiled Souls and Lost Identities}

In the novel, Edith Hope, assuming the pseudonym Vanessa Wilde, writes romantic novels to connect to her self, since she is already alienated to the meanings of words, behaviour in terms of hypocritical middle-class values, thus Edith's mind is confused with "what behaviour becomes a woman" (Brookner: 1993, 40) and in her novels she questions that problematic issue because she could not answer this question in her so-called own life. As a writer of romantic fiction, she feels like herself in the fictive world she creates; however, in society, she feels like the other who has been alienated and exiled like either a detective or a murderer of a detective story since "the detective story theorizes the alienation of meaning in terms of the enmity of the middleclass interior toward immanence, an immanence which the detective threatens to restore by reading disembodied signs (clues)" (Calhoon: 1995, 308). In Hotel $d u L a c$, Edith is alienated from the society she believes she has belonged to. The theory of alienation of meaning in detective story in terms of the enmity of the middle class turns out to be the enmity of the middle class patriarch towards the immanence which Edith, either as a detective or a murderer, threatens to restore by reading disembodied signs in the Hotel du Lac setting. Detective fiction, concerned as it is with "breaking in," sustains this link between the cultivation of the spirit and a physical interior which, like the aesthetic disposition itself, insulates against the struggles of the wide world. The detective's quest for meaning thus has less to do with restoring a lost totality than with exposing the class that made meaninglessness -- in the form of disinterestedness -- a cultural commodity (ibid., 309). Patriarchal society breaks into the lives of females, and turns their bodies into commodities, to be used and abused as the tools of the ideological male point of view. "Detective fiction, originating in the $19^{\text {th }}$ century when the social structure was based on a concept of small communities, served to warn of the consequences of crime. Context of new ideas about identity and society, the interest in matters criminal began to focus on the perpetrator of the crime and his or her motive rather than on the crime and its punishment" (Worthington: 2005, 2). Thus, crime stories are born out of the consequences of social hierarchies, gender roles, materialism and identity crisis. The moments of crisis in detective fictions lead not only to physical murders but also to abstract symbolic murders which are acted out either by society or government, more explicitly by institutionalized patriarchal authorities. Thus, alienated selves become the victims of society, and society itself becomes the source of their alienation; in other words, symbolic deaths. The alienated feel that they are observed and judged by everyone, so they hide themselves, being suspicious of everyone. Walter Benjamin describes these people as flâneurs who are uprooted people: they are at home neither at their classes nor in their birthplaces, but rather only in the crowd. This may seem ironic in Edith Hope's case since as a female, she is supposed to feel secure 
only at home and in her birthplace; however, she does not feel so. Her city is no longer home because it stands for society's hypocrisy. Thus, since she has broken patriarchal societal rules by refusing a status-quo marriage with Geoffrey Long, a prosperous businessman, she is forced to leave home for Hotel du Lac on a lake in Switzerland to come to her senses. The triumph of societal forces, Walter Benjamin argues, was putting the flâneur to use as a detective. As the "physiologies" waned in popularity, perhaps reflecting doubts as to the flâneur's ability to give order to the metropolis and its masses, "the flâneur is ... turned into an unwilling detective" $(1969,40-41)$, as Edith is forced to be. He argues that the flâneur's newfound employment "does him(her) a lot of good socially, for it accredits his(er) ${ }^{2}$ idleness" (ibid.) but it also clearly signals the demise of the flâneur in h(er)is "pure" state. The now productive flâneur-turneddetective was assimilated into the utilitarian society that (s)he had formerly resisted. The rise of the detective reflects society's uneasiness about the flâneur and its pressures to mitigate $\mathrm{h}(\mathrm{er}$ )is elusiveness (ibid., 48). At the end of the novel, Edith, the victimized flâneur who is turned to a detective, is assimilated into the utilitarian society that she has formerly resisted.

Edith Hope, alias Vanessa Wilde as the secret writer of romance, manifests her romantic nature in her romantic books. In contrast to the associations of her surname 'Hope' she is not hopeful at all about society's requirement from women; thus she presents her romantic and wild side through her books, also indicated in her pseudonym, that enables her to be able to endure that hypocritical world. Edith, as a well-educated and independent woman, has difficulty in complying with male-oriented order as she hopes to find true love one day and get married to her prince charming. As the challenger of the established traditional values in the social system through her refusal of a status-quo marriage with Geoffrey Long, she manifests her romantic nature in her belief in the idea of love, in the sense that she must feel attached to a man emotionally and physically in order to be able to think of matrimony. So, even on the morning of her wedding day, Edith is depicted as still thinking about her secret lover, David Simmond, a married man with a family, but not her fiancé, whom she does not love. When she refuses to fall into a loveless relationship with Geoffrey, she is sent to a hotel in Switzerland by her friend Penelope to come back "older, wiser and properly apologetic" (Brookner, op. cit, 8). Penelope's name is etymologically "related to pene 'thread on the bobbin,' from penos 'web,' cognate with Latin pannus 'cloth garment'. Used in English as the type of the virtuous wife (1580) as it was in Latin" (Online Etymology Dictionary). Thus, Penelope could be associated with "THE FATES, Moirae in Greek ... They were three, Clotho, the Spinner, who spun the thread of life;

\footnotetext{
${ }^{2}$ The female pronoun is added by me to the quotations of Walter Benjamin.
} 
Lachesis, the Disposer of Lots, who assigned to each man his destiny; Atropos, she who could not be turned, who carried "the abhorred shears" and cut the thread at death" (Hamilton : 1999, 46).

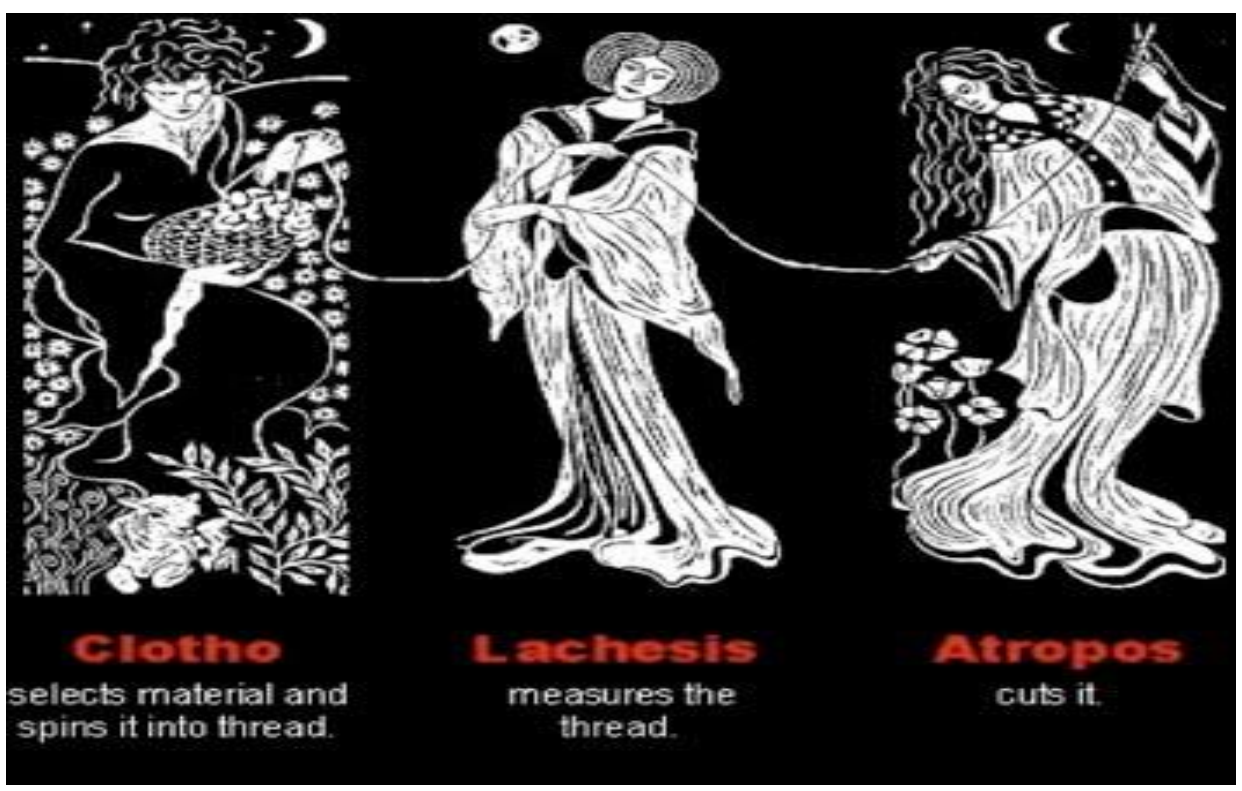

The Greek Goddesses of Fate

Penelope weaves the fate of Edith by sending her into exile to come to her senses to be a virtuous wife according to the patriarchal ideology. Her banishment from society will bring her to her senses: "in dreams she felt both despair and a sort of doomed curiosity, as if she must pursue this path until its purpose were revealed to her" (Brookner, op. cit., 21). The path takes her to the Hotel du Lac which offers a peaceful atmosphere; a family establishment situated on a silent green area near the lake. The hosts of the hotel are particularly detached females: Madame la Comtesse, Mrs. Pusey and her daughter Jennifer, Monica, and Mme Bonueille. At first Edith does not realize why hotel is hosting only females: "Why are they here? But women, women, only women, and I do so love the conversation of men. Oh David, David, she thought" (ibid., 21). In fact she is one of those who is shut and kept there. The hotel's environment offers a restricted area which is depicted as a receding area of grey gardens and unfamiliar plants; an appropriate metaphor for Edith's emotions and anxieties. Although nature is generally depicted as a fertile and beautiful place, it transforms into a grey one in Hotel du Lac. On the one hand, the greyness of nature could be related to Hotel du Lac's hosting dead souls, on the other hand, grey could be associated with Hercule Poirot's words on grey cells referring to the brain, the little grey cells on which one must rely and seek 
the truth within. The grey nature which Edith delves into is appropriate for Edith's emotions and anxieties. It is not only apt for her position as a female in society but also suitable to her being a flâneur-turned-detective in that setting. Greyness of nature activates the little grey cells on which she can rely on so that she could seek truth within. Edith's link to Belgian detective Hercule Poirot of Agatha Christie's novels could be understood through her first implications regarding Madame la Comtesse's physical outlook since she thinks that she is a Belgian confectioner's widow walking with a stick (ibid., 11). All these descriptional details recall Hercule Poirot who also carries a stick in his hand and Edith, in the beginning of the novel by giving a reference to Hercule Poirot, remembers her gray cells which will lead her to the full realization.

Although Edith feels as a prisoner in "the outline of the gaunt remains of a $13^{\text {th }}$ century castle" (ibid., 7), she knows that she will adapt herself to that environment so that she could claim her "peaceable existence": “... (and I notice the leaves of that plant are quite immobile) I shall be allowed back, to resume my peaceable existence, and to revert to what I was before I did that apparently dreadful thing... (ibid., 9). In fact, she knows that her existence in the city will not be allowed to find its peace. The ironic contrast between curative stay and grey solitude which reminds death represents symbolic death of Edith because she has been sent to exile and punished by the society namely external authority. Atmosphere of the hotel and the environment accompanies her symbolic death since grey solitude and immobile plants reflect stillness, stagnant and dull world. Yet the hotel also resembles a crime scene for Edith's detective-inspired consciousness: the "lakes suggest the Earth's eye, through which the inhabitants of the Underworld are able to gaze upon humans, animals and plants" (Chevalier and Gheerbrant: 1996, 585). Lakes are also depicted as the mysterious crime scenes in many detective novels since "Nature should reflect its human inhabitants, i.e., it should be the Great Good Place; for the more Eden-like it is, the greater the contradiction of murder. The country is preferable to the town" (Auden: 1948, 5). Thus, in a way, Edith is returned to the Garden of Eden from which she has been expelled before. The very same quotation which represents her exile becomes the symbolic representation of females' condemnation to eternal damnation, putting an evil slant on "... the cheerful uplands to the south a rising back drop of apple trees, the fruit sparkling with emblematic significance" (Brookner, op. cit., 7). There is no escape either in city or in nature since both represent the very same destiny in all cases: the death of identity. However, this time, she has more experience, awareness and suspicion of a flâneur detective thinking about the "mysterious opacity with which she had been presented" (ibid., 8) by the hotel near the lake. The word mystery is going to be repeated by Edith continuously throughout the subsequent action. 
The only man at Hotel du Lac, Mr Neville, who has been betrayed by his wife and whom later proposes to Edith, offering a social position, confidence and sophistication through marriage, thinks that the "hotel is hardly the place for you [Edith]. It seems to be permanently reserved for women, and for a certain kind of woman. Cast off or abandoned, paid to stay away, or to do harmless womanly things, like spending money on clothes. The very tenor of the conversation excludes men. You must be bored stiff" (ibid., 93). The cast off women, dominant Mrs Pusey and her daughter Jennifer, weak Monica, and deaf Mme Bonueille and also betrayed Mr. Neville make her realize that she will be either cured by coming to her senses or will be cast off or abandoned, excluding herself from society which she has already been forced to do. However according to the theory of the detective fiction, Michael Holquist states that the detective is considered to be "the essential metaphor for order", the "instrument of pure logic" (Landrum: 1999, 79). While Edith is addressed as a pure romantic (Brookner, op. cit., 95) by Philip Neville, in fact she is the only logical person among the women in the hotel. However in her own society, Edith is condemned as the source of chaos since she does not conform to the norms of the patriarchal society she lives in. Edith both becomes the detective and also the victim in Hotel Du Lac where the transitory nature of life and people are emphasized. Both as the detective and also the victim she escapes to her fiction: "...Embroiled in her fictional plot, the main purpose of which was to distance those all real circumstances over which she could exert no control, she felt a weariness that seemed to preclude any enthusiasm, any initiative, any relaxation. Fiction... would have to come to her aid..." (ibid., 66). Fiction becomes an important means for Edith to express her identity that is limited by society. She uses her fiction not only to shape her identity, but also to understand other characters' lives. For example, Monica is sent to the hotel by her "noble husband, in urgent need of an heir, (...) with instructions to get herself into working order; should this not come to pass, Monica will be given her cards and told to vacate the premises so that Sir John can make alternative arrangements" (ibid., 80). Monica's situation is not different from Edith's. She does not come to hotel by her own choice; she has been forced and dispatched by her husband with instructions. Monica is like an object; a commodity that will give birth to a male heir whom her husband will use as an indication of honour.

The whole sorry business of baiting the sexual trap was uncovered by Monica's refusal to behave in herself in a way becoming to a wife; by sheer effrontery she would damage her husband's pride, humble him into keeping her, or if not, ruin his reputation. And although cast adrift while he pursued other interests, other plans, she was waiting for him, as one waits for an enemy; once they met, she would, by dint of insult and outrage, reawaken the 
fury that had once been between them. And until he came she would spend his money, waste his time, meditate her revenge (ibid., 82).

Monica is aware of being an object for her husband and "...she hates and fears her husband, but only because he has not protected her, and she sees herself condemned to loneliness and exile... Her fine hieratic face droops into sadness as she contemplates what she can see of her future" (ibid., 81). Hence, she needs her other self in order to achieve a reciprocal relationship, to share her anxieties and to feel alive. Monica finds relief with Edith since she is the only one who listens to her.

During her stay at Hotel du Lac, Edith realizes that her dilemmas, confusion and destruction are caused by society on her walks and tries to bring order to her nature and identity by getting rid of her dilemmas and complexities.

Then there was nothing to do but go for a walk. Through the silent garden, through an iron gate... and along the shore of the lake she walked in the fading light of that grey day. The silence engulfed her... This solitude to which she had been banished by those who knew best, was not what she had had in mind. And this dim, veiled, discreet, but unfriendly weather...The lake was utterly still; a solitary lamp gleamed above her... (ibid., 21).

The garden symbolizes the escapism from the society and civilization since it is the place where Edith gets rid of norms of the society. She was peaceful at home but not at the outer space from which she has been totally expelled. While Edith is walking along the shore of the lake, the silence engulfs her, but this provides her with the pretext for a moment of profound selfdiscovery. The natural truth is that individuals are imprisoned due to the limiting norms and rules of society. Realizing this and "looking back, she [Edith] saw that on that occasion she had been braver, younger, more determined to sit out her banishment and to return home unchanged ${ }^{3}$ by it" (ibid., 174). This is also seen at the end of the novel when in her letter Edith crosses out the words "Coming home", and simply writes "Returning" (ibid., 184), so there seems to be no hope for Edith. There is only hope for Edith when she isolates herself from society by tending her garden - an act of deliberate personal detachment of the protagonist from society: "She would miss the garden most, she thought, although she was not really a gardener" (ibid., 120). Because the garden for her also represents the garden of literature, eternal cycle of fertility and creativity. Also gardener image can be connected with God since in the Bible, God plants a garden eastward in Eden so in a way she assumes the role of God which is the characteristic of a detective and also naturally of artists. Edith thinks of her dream house in which there will be a husband she loves however, she realizes that it is not the house that she wants, but a garden representing her creativity, her self. According to Walter Benjamin in his

${ }^{3}$ My emphasis. 
unfinished work of The Arcades Project, dream houses of the collective (are) arcades, winter gardens, panoramas, factories, wax museums, casinos, railroad stations $(2003,210)$. In fact, in her dream house, Edith does not want a winter garden; she wants a garden not only valid for winter but for all seasons, since the garden is associated with her creativity. And she knows that she is not going to write if there is none: "and there was no garden, so that her day would have an entirely different pattern when her writing time was over. But then she would never write again. She would have that life that she supposed other women have: shopping, cooking, arranging dinner parties, meeting friends for lunch" (Brookner, op. cit., 123). Edith despises women shopping, cooking, arranging dinner parties and finds the conversation between women generally overtly conventional, dull and simple. While she describes the females in the hotel she tries to match their outlooks with their characters like a detective as could be identified in her words on Mrs. Pusey's daughter:

The daughter must be about twenty-five, thought Edith, unmarried, but not worried about it. 'She's in no hurry,' she could imagine the mother saying, with her fine smile. 'She's quite happy as she is.' And the daughter would blush and bridle, thus inviting lubricious speculation on the part of the elderly gentlemen who would, Edith was sure, be in relatively constant attendance on the mother. I must stop this, she said to herself. I do not have to make up their lives for them" (ibid., 19).

The subjects women talk about in the hotel are generally limited to the context of fashion and the opposite sex, which Edith finds insipid and shallow. According to Walter Benjamin,

Fashion prescribes the ritual according to which the commodity fetish demands to be worshipped. For Fashion was never anything other than the parody of the motley cadaver, provocation of death through the woman, and bitter colloquy with decay whispered between shrill bursts of mechanical laughter. That is fashion and that is why she changes so quickly; she titillates death and is already something different, something new, as he casts about to crush her (op. cit., 39).

Edith confirms this idea in the character of Mrs. Pusey who reminds us of the Fashion that is presented as the sister of Death in the "Dialogue between Fashion and Death" of Giacomo Leopardi (1798-1837). In this work "Death wants fashion, as a good and affectionate sister, to help him to prevent such a result (power of fashion) and to attain its very opposite, even more effectually and more expeditiously than he has yet done" $(1906,74)$. Since Mrs. Pusey is very much obsessed with fashion, she buys fancy clothes for her daughter Jennifer. Thus, both Mrs. Pusey and Jennifer are identified with death, which also signifies the unhealthy relationship between mother and daughter.

Edith trapped among those females, is labelled as an outcast and alienated character. However, at the end of the novel, she solves the mystery of 
both her problematic identity and also the others'. She is well aware of the fact that disparity between social values and the individual's personal aspirations, and desires cannot be eliminated. Discontinuity, disruption, dislocation, indeterminacy of the female identity will go on as long as females conform to the rules of the society formed by the patriarchy. Edith sees the hypocrisy, tries to conform to it, but learns that she cannot be fully part of it.

\section{Conclusion}

In conclusion, Hotel du Lac delineates the human condition of detachment, rendering the issue of the possible reactions individuals give as a solution to the dire condition of isolation. It is emphasised in the novel that the ones who do not conform to the rules of the society are castigated with the bitterness of detachment and it is very likely that these characters relinquish their integrity in their struggle for survival. Edith is depicted as a problematic character by society which in fact imposes its own weakness on her. Edith, both being victim and detective, tries to sort out the problematic situations behind the other women's outcast states to solve the so-called mystery presented by another voice of the patriarch, Penelope. For Penelope and other representatives of the traditional male system, being the real murderer will be echoed throughout centuries unless the suppression is not transferred to other centuries by females. Otherwise, what is left for Edith is only to return that hypocritical system with full awareness which proves that females are doomed to live through that system, either in the city or in nature.

\section{WORKS CITED} May Issue.

AUDEN, W. H. (1948), “The Guilty Vicarage”, Harper's Magazine,

BAUDELAIRE, Charles, (1954), "Le Voyage", Willima Aggeler (trans), The Flowers of Evil, Fresno, CA: Academy Library Guild.

BENJAMIN, Walter (2003), Walter Benjamin: 1938-1940 v. 4: Selected Writings.

(1999), The Arcades Project. Howard Eiland and Kevin McLaughlin (trans.), Cambridge, Massachusetts, and London, England: The Belknap Press of Harvard University,.

(1969), The Paris of the Second Empire in Baudelaire and

Some Motifs in Baudelaire, first published in one volume as Charles Baudelaire, Ein Lyriker im Zeitalter des Hochkapitalismus, Rolf Tiedemann (ed.), Suhrkamp Verlag.

BROOKNER, Anita (1993), Hotel du Lac, London: Penguin Books.

CALHOON, Kenneth S. (1995), "The Detective and the Witch: Local Knowledge and the Aesthetic Pre-History of Detection" Comparative Literature, Vol. 47, No. 4 (Autumn), pp. 307-329. Published by: Duke 
University Press on behalf of the University of Oregon Stable URL: http://www.jstor.org/stable/1771326. Accessed: 25/02/2014 10:47.

CHEVALIER, Jean and GHEERBRANT, Alain (1996), Dictionary of Symbols. Trans. by John Buchanan-Brown, Penguin Books.

HAMILTON, Edith (1999), Mythology: Timeless Tales of Gods and Heroes. New York \& Boston: Grand Central Publishing.

LANDRUM, Larry (1999), N. American Mystery and Detective Novels: A Reference Guid. Greenwood Publishing Group,.

LEOPARDI, Giacomo (1906), The World's Wit and Humor, Vol. XIII, Italian-Spanish, New York: TheReview of Reviews Company, http://elfinspell.com/WitandHumorLeopardi.html.

PENELOPE,http://www.etymonline.com/index.php?allowed_in_frame $=0 \&$ search $=$ penelope \&searchmode $=$ none. Online Etymology Dictionary.

PHANESSA,http://www.etymonline.com/index.php?allowed_in_frame $=0 \&$ search $=$ phanessa\&searchmode $=$ none. Online Etymology Dictionary.

PUSEY, http://www.surnamedb.com/surname.aspx?name=Pusey.

WORTHINGTON, Heather (2005), The Rise of the Detective in Early Nineteenth Century Popular Fiction, Palgrave Macmillan. 